\title{
Multiplication of Phalsa (Grewia asetica L.) Cv. Dwarf Type through Hardwood Stem Cutting Under Srinagar Garhwal Himalayas
}

\author{
Krishan Kumar Singh*
}

\author{
Department of Horticulture, Chauras Campus, HNB Garhwal University, \\ Srinagar (Garhwal) 246174, Uttarakhand, India \\ *Corresponding author
}

\begin{tabular}{|c|c|}
\hline & A B S T R A C T \\
\hline $\begin{array}{l}\text { Phalsa, } \\
\text { IBA, } \\
\text { NAA, } \\
\text { Planting time and } \\
\text { rooting }\end{array}$ & \multirow{3}{*}{$\begin{array}{l}\text { An experiment was conducted to study the Multiplication of Phalsa (Grewia asetica } \\
\text { L.) Cv. Dwarf Type Through Hardwood Stem Cutting Under Srinagar Garhwal } \\
\text { Himalayas during the rainy season 2012-13 at Horticultural Research Centre, Chauras } \\
\text { Campus, H.N.B. Garhwal University, Srinagar, Garhwal, Uttarakhand, India. The } \\
\text { experiment was laid out in Factorial Randomized Block Design (FRBD) with three } \\
\text { main factors (1000ppm IBA, 1000ppm NAA and Control) and four sub factors (June, } \\
\text { July, August and September). Results of the investigation showed that the maximum } \\
\text { number of sprouted cutting (5.083), survival percentage of cutting (50.833), length of } \\
\text { longest sprout ( } 7.794 \mathrm{~cm}) \text {, diameter of thickest sprout }(1.848 \mathrm{~mm}) \text {, number of leaves } \\
\text { (4.917), number of sprout per cutting (2.333), percentage of rooted cutting ( } 48.333 \%) \text {, } \\
\text { number of primary roots ( } 7.158) \text {, diameter of thickest root (1.681mm), length of } \\
\text { longest root (7.158), fresh weight of root (1.033g) and dry weight of root }(0.649 \mathrm{~g}) \text { was } \\
\text { recorded under } 1000 \mathrm{ppm} \text { concentration of IBA with mid August planting time. }\end{array}$} \\
\hline Article Info & \\
\hline $\begin{array}{l}\text { Accepted: } \\
\text { 22 January } 2017 \\
\text { Available Online: } \\
\text { 10 February } 2017\end{array}$ & \\
\hline
\end{tabular}

\section{Introduction}

Phalsa (Grewia asiatica L.) belongs to genus Grewia and family Tiliaceae, is a native to south Asia from India. Phalsa is a small bushy in nature and preferred as an ideal crop for growing in arid and hot regions. It can be grown successfully on the slop of hills. Phalsa is a very popular fruit in our country and is commercially grown particularly in states of Uttar Pradesh, Bihar, Madhya Pradesh and Maharastra. The genus Grewia comprises approximately 150 species of shrubs and small trees, and is the only genus in the family that yields edible fruits. The phalsa fruits are good source of vitamin ' $C$ ' and 'A'. Ripe fruits of phalsa are consumed fresh, as desserts, or processed into refreshing fruit enjoyed in India during hot summer months. The leaves are believed to have antibiotic properties hence, applied on skin eruptions and they are known to have antibiotic action.

The phalsa plant is propagated by rooting of hardwood cuttings. Hardwood cutting and date of planting influence rooting of phalsa. The time of preparation of cuttings in phalsa greatly affected the extent and success of root formation, the optimal time of cuttings preparation and planting is related to the physiological condition and environmental conditions of the plant (Jadhav, 2007). This 
may be affected by season and several factors such as nutrient availability, temperature, and light to the rooting percentage of cuttings. The low rooting percentage during winter may be attributed to temperature level at the time of planting. Application of auxin has been found to increase the histological features like formation of callus tissue and differentiation of vascular tissues. Devi et al., (2016) showed that the maximum shoot and rooting performance was observed under $300 \mathrm{ppm}$ concentration of IBA with planted on 30th July. Singh et al., (2015) was observed that the phalsa cuttings treated with IBA 2000ppm performed best in all aspects, as length of shoot, length of root rooting and percentage root. Intermittent mist is often used on cuttings because it shortens the temperature of the leaves, increases relative humidity and lowers respiration around the leaf surface. For that, the present investigate was undertaken with the following objectives: (a)To find out the effects of various planting time on response and performance of rooting in stem cuttings of phalsa. (b)To determine the effect of various rooting media on response and performance of rooting in stem cuttings of phalsa.

\section{Materials and Methods}

The experiment site was conducted under mist chamber at Horticulture Research Center, Chauras Campus. Geographically Srinagar valley is spread between latitude $30^{\circ}$, 12 ' 0 " to $30^{\circ} 13$ ' 4" North and longitude $78^{\circ}$ $0^{\prime} 45^{\prime}$ " to $78^{0} 0$ ' $50^{\prime \prime}$ East. The valley is about $6 \mathrm{~km}$ long and 1 to $1.2 \mathrm{~km}$ wide located on both side of famous Alaknanda River at an elevation $540 \mathrm{~m}$ above MSL and about 132 $\mathrm{km}$ from Haridwar in Himalayan region. The valley shows a semi-arid and sub-tropical climate. Except during rainy season rest of months are usually dry with exception occasional showers during winter or early spring. The average minimum and maximum temperature, relative humidity and rainfall vary from $7.44^{0} \mathrm{C}$ to $34.3^{0} \mathrm{C}, 62.24 \%$ and 2.60 to $235.45 \mathrm{~mm}$ respectively.

An experiment was conducted to study the influence of four collecting times (June, July, August and September) and two bio regulators (1000ppm NAA, 1000ppm IBA and Control) on rooting characteristics of phalsa (Grewia asiatica) in 2012-2013 under mist chamber growing condition. Hardwood cuttings of Grewia asiatica were collected from 5 to 7 year old plants and $20 \mathrm{~cm}$ long cuttings with basal portion. For preparing the rooting media, farm yard manure and sandy soil in ratio of $1: 1$ by $\mathrm{v} / \mathrm{v}$ were mixed thoroughly, cleaned for grasses and stones, then the mixture was filled in root trainers (Singh et al., 2016).

The cuttings basal ends were dipped in dilute solutions, 1000 ppm IBA, 1000 ppm NAA and control by quick dip method for 10 seconds before planting in the rooting medium (Oni, 1987 and Singh et al., 2011). The experiment was laid out in FRBD and replicated thrice with 10 cuttings in each treatment. The cuttings (nine numbers per treatment per replication) were carefully removed from the pots and dipped in water to remove the soil particles adhering to roots to record the observations pertaining to roots viz., percentage of cutting rooted, length of longest root and diameter of root except for the observations on various stem leaf characters and all other were recorded after planting. The recorded data were analysed through statistical software for observation the parameter were statically significant $(0.05 \%)$ statically difference (FRBD) as described by Cochran and Cox (1992).

\section{Results and Discussion}

The results of the survival parameters of Grewia asiatica cuttings are showed in the tables 1 and 2. Significantly the maximum number of sprouted cutting (5.083), survival 
percentage of cutting (50.833), length of longest sprout $(7.794 \mathrm{~cm})$, diameter of thickest sprout $(1.848 \mathrm{~mm})$, number of leaves (4.917), number of sprout per cutting (2.333), percentage of rooted cutting (48.333\%), number of primary roots (7.158), diameter of thickest root $(1.681 \mathrm{~mm})$, length of longest root (7.158), fresh weight of root $(1.033 \mathrm{~g})$ and dry weight of root $(0.649 \mathrm{~g})$ was recorded under $\mathrm{C}_{1}$ (1000ppm concentration of IBA), while the minimum number of sprouted cutting (2.750), survival percentage of cutting $(27.500 \%)$, length of longest sprout $(6.751 \mathrm{~cm})$, length of longest root $(6.860 \mathrm{~cm})$, fresh weight of root $(0.842 \mathrm{~g})$, diameter of thickest sprout $(1.653 \mathrm{~mm})$, number of leaves (3.861), number of sprout per cutting (1.806), percentage of rooted cutting (24.167\%), number of primary roots (6.788), diameter of thickest root $(1.248 \mathrm{~mm})$, and dry weight of root $(0.447 \mathrm{~g})$ was recorded under $\mathrm{C}_{0}$ (control) treatments. The positive relationship has been observed between rooting and IBA treatment by Goutam and Chauhan (1990). Singh et al., (2015) showed that phalsa rooting percentage, survival percentage, length of shoot, length of root and thickening of root was recorded under IBA 2000ppm with mist chamber growing condition.

The effectiveness of auxin to rooting percentage of the cuttings could be through enhancing cambial activity and differentiation of root primordia. Davies and Joiner (1980) observed that the stimulating redistribution and mobilization of some auxin cofactors towards base of the cuttings. Maximum percentage of rooting in cuttings treated with IBA may be ascribed to the maximum partitioning of photosynthesis towards root development. It is also well known that success of vegetative propagation through cuttings of woody plants depends on physiological capacity and genetic for adventitious root formation (Hartman et al., 2002). The findings of present study are similar to the results of in Gupta et al., (2002) in bougainvillea and Luqman et al., (2004) in guava (Psidium guajava L.).

In case of time of planting, significantly the maximum number of sprouted cutting (5.666), survival percentage of cutting $(56.667 \%)$, length of longest sprout $(9.218 \mathrm{~cm})$, diameter of thickest sprout $(2.370 \mathrm{~mm})$, number of leaves (5.814), percentage of rooted cutting $(54.444 \%)$, number of primary roots $(8.607)$, diameter of thickest root $(1.774 \mathrm{~mm})$, length of longest root (8.607), fresh weight of root $(0.996 \mathrm{~g})$ and dry weight of root $(0.628 \mathrm{~g})$ was observed under $\mathrm{T}_{3}$ (Mid August) planting time and the number of sprout per cutting (2.370) was recorded under $\mathrm{T}_{2}$ (Mid July) planting time while the minimum number of sprouted cutting (1.556), survival percentage of cutting (15.556\%), length of longest sprout $(5.242 \mathrm{~cm})$, diameter of thickest sprout $(1.278 \mathrm{~mm})$, number of primary roots (1.778), number of leaves (2.667), number of sprout per cutting (1.778), percentage of rooted cutting (14.444\%), number of primary roots (5.444), diameter of thickest root $(1.092 \mathrm{~mm})$, length of longest root $(5.444 \mathrm{~cm})$, fresh weight of root $(0.826 \mathrm{~g})$ and dry weight of root $(0.444 \mathrm{~g})$ was recorded under $\mathrm{T}_{4}$ (Mid September) planting time. July and August months have been found to induce better root system in phalsa cuttings.

This is due to enhanced activity of hydrolyzing enzymes and adequate mobilization of reserve food material. The enhanced hydrolysis activity in the presence of optimum production of endogenous hormones was responsible for the increased rooting in cuttings (Nanda and Anand, 1970). Yadav et al., (1978) have shown that the highest percentage of rooting in hardwood cuttings of bougainvillea planted was in August. The rooting behaviour of cuttings may have varied with the seasons and low temperature adversely affecting rooting. 


\section{Int.J.Curr.Microbiol.App.Sci (2017) 6(2): 1173-1178}

Table.1 Effect of bio regulator and planting time on the shooting performance of phalsa (Grewia asetica L.)

\begin{tabular}{|c|c|c|c|c|c|c|c|c|c|c|c|c|c|c|c|}
\hline \multirow[t]{2}{*}{ Rooting Media } & \multicolumn{5}{|c|}{ Number of sprouted cutting } & \multicolumn{5}{|c|}{ Survival percentage of cutting } & \multicolumn{5}{|c|}{ Length of longest sprout $(\mathrm{cm})$} \\
\hline & $\mathrm{T}_{1}$ & $\mathrm{~T}_{2}$ & $\mathrm{~T}_{3}$ & $\mathrm{~T}_{4}$ & Mean & $\mathrm{T}_{1}$ & $\mathrm{~T}_{2}$ & $\mathrm{~T}_{3}$ & $\mathrm{~T}_{4}$ & Mean & $\mathrm{T}_{1}$ & $\mathrm{~T}_{2}$ & $\mathrm{~T}_{3}$ & $\mathrm{~T}_{4}$ & Mean \\
\hline $\mathrm{C}_{0}$ (Control) & 2.333 & 3.000 & 4.000 & 1.667 & 2.750 & 23.333 & 30.000 & 40.000 & 16.667 & 27.500 & 7.400 & 6.407 & 8.133 & 5.063 & 6.751 \\
\hline $\mathrm{C}_{1}(1000 \mathrm{ppm}$ IBA $)$ & 5.333 & 5.667 & 7.667 & 1.667 & 5.083 & 53.333 & 56.667 & 76.667 & 16.667 & 50.833 & 6.823 & 7.177 & 11.577 & 5.600 & 7.794 \\
\hline $\mathrm{C}_{2}(1000 \mathrm{ppm}$ NAA) & 4.000 & 4.333 & 5.333 & 1.333 & 3.750 & 40.000 & 43.333 & 53.333 & 13.333 & 37.500 & 7.587 & 7.520 & 8.133 & 5.063 & 7.076 \\
\hline Mean & 3.889 & 4.333 & 5.667 & 1.556 & & 38.889 & 43.333 & 56.667 & 15.556 & & 7.270 & 7.034 & 9.281 & 5.242 & \\
\hline \multicolumn{16}{|l|}{$\mathrm{CD} 0.5 \%$} \\
\hline Planting Time (T) & \multicolumn{5}{|c|}{0.639} & \multicolumn{5}{|c|}{6.390} & \multicolumn{5}{|c|}{0.690} \\
\hline Growth Regulator $(\mathrm{C})$ & \multicolumn{5}{|c|}{0.553} & \multicolumn{5}{|c|}{5.534} & \multicolumn{5}{|c|}{0.598} \\
\hline $\mathrm{T} \times \mathrm{C}$ & \multicolumn{5}{|c|}{1.107} & \multicolumn{5}{|c|}{11.067} & \multicolumn{5}{|c|}{1.195} \\
\hline
\end{tabular}

Table.2 Effect of bio regulator and planting time on the shooting performance of phalsa (Grewia asetica L.)

\begin{tabular}{|c|c|c|c|c|c|c|c|c|c|c|c|c|c|c|c|}
\hline \multirow[t]{2}{*}{ Rooting Media } & \multicolumn{5}{|c|}{ Diameter of thickest sprout } & \multicolumn{5}{|c|}{ Number of leaves } & \multicolumn{5}{|c|}{ Number of sprout per cutting } \\
\hline & $\mathrm{T}_{1}$ & $\mathrm{~T}_{2}$ & $\mathrm{~T}_{3}$ & $\mathrm{~T}_{4}$ & Mean & $\mathrm{T}_{1}$ & $\mathrm{~T}_{2}$ & $\mathrm{~T}_{3}$ & $\mathrm{~T}_{4}$ & Mean & $\mathrm{T}_{1}$ & $\mathrm{~T}_{2}$ & $\mathrm{~T}_{3}$ & $\mathrm{~T}_{4}$ & Mean \\
\hline $\mathrm{C}_{0}$ (Control) & 1.500 & 1.667 & 2.110 & 1.333 & 1.653 & 3.833 & 4.333 & 4.943 & 2.333 & 3.861 & 2.333 & 2.000 & 1.557 & 1.333 & 1.806 \\
\hline $\mathrm{C}_{1}(1000 \mathrm{ppm}$ IBA) & 1.667 & 2.000 & 2.557 & 1.167 & 1.848 & 4.000 & 5.333 & 7.333 & 3.000 & 4.917 & 1.777 & 2.110 & 3.110 & 2.333 & 2.333 \\
\hline $\mathrm{C}_{2}$ (1000ppm NAA) & 1.500 & 1.833 & 2.443 & 1.333 & 1.778 & 4.000 & 4.167 & 5.167 & 2.667 & 4.000 & 2.000 & 3.000 & 1.333 & 1.667 & 2.000 \\
\hline Mean & 1.556 & 1.833 & 2.370 & 1.278 & & 3.944 & 4.611 & 5.814 & 2.667 & & 2.037 & 2.370 & 2.000 & 1.778 & \\
\hline \multicolumn{16}{|l|}{ C D $0.5 \%$} \\
\hline Planting Time (T) & \multicolumn{5}{|c|}{0.359} & \multicolumn{5}{|c|}{0.412} & \multicolumn{5}{|c|}{ NS } \\
\hline Growth Regulator (C) & \multicolumn{5}{|c|}{ NS } & \multicolumn{5}{|c|}{0.357} & \multicolumn{5}{|c|}{ NS } \\
\hline $\mathrm{T} \times \mathrm{C}$ & \multicolumn{5}{|c|}{ NS } & \multicolumn{5}{|c|}{0.714} & \multicolumn{5}{|c|}{1.122} \\
\hline
\end{tabular}

$\mathrm{T}_{1}=$ June, $\mathrm{T}_{2}=$ July, $\mathrm{T}_{3}=$ August and $\mathrm{T}_{4}=$ September, $\mathrm{C}_{1}=1000 \mathrm{ppm} \mathrm{IBA,} \mathrm{C}_{2}=1000 \mathrm{ppm}$ NAA and $\mathrm{C}_{0}=$ Control (distilled water) 
Table.3 Effect of bio regulator and planting time on the rooting performance of phalsa (Grewia asetica $\mathrm{L}$.)

\begin{tabular}{|c|c|c|c|c|c|c|c|c|c|c|c|c|c|c|c|}
\hline \multirow[t]{2}{*}{ Rooting Media } & \multicolumn{5}{|c|}{ Percentage of rooted cutting } & \multicolumn{5}{|c|}{ Number of primary roots } & \multicolumn{5}{|c|}{ Diameter of thickest root (mm) } \\
\hline & $\mathrm{T}_{1}$ & $\mathrm{~T}_{2}$ & $\mathrm{~T}_{3}$ & $\mathrm{~T}_{4}$ & Mean & $\mathrm{T}_{1}$ & $\mathrm{~T}_{2}$ & $\mathrm{~T}_{3}$ & $\mathrm{~T}_{4}$ & Mean & $\mathrm{T}_{1}$ & $\mathrm{~T}_{2}$ & $\mathrm{~T}_{3}$ & $\mathrm{~T}_{4}$ & Mean \\
\hline $\mathrm{C}_{0}$ (Control) & 20.000 & 26.667 & 36.667 & 13.333 & 24.167 & 6.800 & 7.377 & 7.227 & 5.750 & 6.788 & 1.330 & 1.220 & 1.440 & 1.000 & 1.248 \\
\hline $\mathrm{C}_{1}(1000 \mathrm{ppm}$ IBA) & 50.000 & 53.333 & 73.333 & 16.667 & 48.333 & 7.070 & 6.277 & 10.380 & 4.907 & 7.158 & 1.557 & 1.667 & 2.333 & 1.167 & 1.681 \\
\hline $\mathrm{C}_{2}$ (1000ppm NAA) & 36.667 & 40.000 & 53.333 & 13.333 & 35.833 & 6.473 & 7.077 & 8.213 & 5.677 & 6.860 & 1.220 & 1.330 & 1.550 & 1.110 & 1.303 \\
\hline Mean & 35.556 & 40.000 & 54.444 & 14.444 & & 6.781 & 6.910 & 8.607 & 5.444 & & 1.369 & 1.406 & 1.774 & 1.092 & \\
\hline \multicolumn{16}{|l|}{ C D $0.5 \%$} \\
\hline Planting Time $(\mathrm{T})$ & \multicolumn{5}{|c|}{2.660} & \multicolumn{5}{|c|}{0.974} & \multicolumn{5}{|c|}{0.248} \\
\hline Growth Regulator (C) & \multicolumn{5}{|c|}{2.304} & \multicolumn{5}{|c|}{ NS } & \multicolumn{5}{|c|}{0.215} \\
\hline $\mathrm{T} \times \mathrm{C}$ & \multicolumn{5}{|c|}{ NS } & \multicolumn{5}{|c|}{1.687} & \multicolumn{5}{|c|}{ NS } \\
\hline
\end{tabular}

Table.4 Effect of bio regulator and planting time on the rooting performance of phalsa (Grewia asetica $\mathrm{L}$.)

\begin{tabular}{|c|c|c|c|c|c|c|c|c|c|c|c|c|c|c|c|}
\hline \multirow[t]{2}{*}{ Rooting Media } & \multicolumn{5}{|c|}{ Length of longest root $(\mathrm{cm})$} & \multicolumn{5}{|c|}{ Fresh weight of root (g) } & \multicolumn{5}{|c|}{ Dry weight of root $(\mathrm{g})$} \\
\hline & $\mathrm{T}_{1}$ & $\mathrm{~T}_{2}$ & $\mathrm{~T}_{3}$ & $\mathrm{~T}_{4}$ & Mean & $\mathrm{T}_{1}$ & $\mathrm{~T}_{2}$ & $\mathrm{~T}_{3}$ & $\mathrm{~T}_{4}$ & Mean & $\mathrm{T}_{1}$ & $\mathrm{~T}_{2}$ & $\mathrm{~T}_{3}$ & $\mathrm{~T}_{4}$ & Mean \\
\hline $\mathrm{C}_{0}$ (Control) & 6.473 & 7.077 & 8.213 & 5.677 & 6.860 & 0.860 & 0.880 & 0.870 & 0.757 & 0.842 & 0.450 & 0.413 & 0.563 & 0.360 & 0.447 \\
\hline $\mathrm{C}_{2}(1000 \mathrm{ppm}$ IBA) & 7.070 & 6.277 & 10.380 & 4.907 & 7.158 & 0.967 & 1.030 & 1.147 & 0.987 & 1.033 & 0.627 & 0.687 & 0.733 & 0.550 & 0.649 \\
\hline $\mathrm{C}_{1}(1000 \mathrm{ppm}$ NAA) & 6.800 & 7.377 & 7.227 & 5.750 & 6.788 & 0.877 & 0.867 & 0.970 & 0.733 & 0.862 & 0.477 & 0.443 & 0.587 & 0.423 & 0.483 \\
\hline Mean & 6.781 & 6.910 & 8.607 & 5.444 & & 0.901 & 0.926 & 0.996 & 0.826 & & 0.518 & 0.514 & 0.628 & 0.444 & \\
\hline \multicolumn{16}{|l|}{ C D $0.5 \%$} \\
\hline Planting Time $(\mathrm{T})$ & \multicolumn{5}{|c|}{0.974} & \multicolumn{5}{|c|}{0.116} & \multicolumn{5}{|c|}{0.093} \\
\hline $\begin{array}{l}\text { Growth Regulator } \\
\text { (C) }\end{array}$ & \multicolumn{5}{|c|}{ NS } & \multicolumn{5}{|c|}{0.100} & \multicolumn{5}{|c|}{0.081} \\
\hline $\mathrm{T} \times \mathrm{C}$ & \multicolumn{5}{|c|}{1.687} & \multicolumn{5}{|c|}{ NS } & \multicolumn{5}{|c|}{ NS } \\
\hline
\end{tabular}

$\mathrm{T}_{1}=$ June, $\mathrm{T}_{2}=$ July, $\mathrm{T}_{3}=$ August and $\mathrm{T}_{4}=$ September, $\mathrm{C}_{1}=1000 \mathrm{ppm} \mathrm{IBA}, \mathrm{C}_{2}=1000 \mathrm{ppm}$ NAA and $\mathrm{C}_{0}=$ Control (distilled water)

IBA $=$ Indole butyric acid, NAA $=$ Naphthalene acetic acid 
The low rooting percentage during winter may be attributed to temperature level at the time of planting. The increased hydrolytic activity in presence of applied IBA coupled with appropriate time of planting might be responsible for the enhanced percentage of rooted cuttings. Low nitrogen and High carbohydrate have been observed to favour root formation (Singh 2016). The present findings are similar to the findings of Kumar et al., (2007) in phalsa (Table 3 and 4).

In conclusion, it is suggested that 1000ppm concentration of IBA with August planting time gives the overall best performance under mist condition to produce tallest plant of phalsa (Grewia asiatica) cv. dwarf type within a short time and recommend for commercial vegetative multiplication until additional discoveries are made.

\section{References}

Davies and Joiner 1980. Growth Regulator Effects on Adventitious Root Formation in Leaf Bud Cuttings of Juvenile and Mature Ficus pumila. J. Amr. Soc. Hort. Sci., 105: 91-95.

Devi, J., Bakshi, P., Wali, V.K., Kour, K. and Sharma, N. 2016. Role of Auxin and Dates of Planting on Growth of Cutting Raised Plantlets of Phalsa (Grewia asiatica L.). The Bioscan., 11(1): 535-537.

Gautam, D.R. and Chauhan, J.S. 1990. Standardization of IBA concentration and season on rooting of wild olive cutting under intermittent mist. Indian J. Hort., 47(3): 278-285.

Gupta V.M., Banerji, B.K. and S.K. 2002 Effect of auxin on the rooting and sprouting behavior of stem cuttings of Bougaainvillea cv. Los Banos Variegata Silver-Margin under mist. Haryana J. Agri. Sci., 31(1-2): 42-44.

Hartmann, H.T., Kester, D.E., Devies, F.T. and Geneve, R.L. 2002. Plant Propagation: Principles and Practices. 7th ed. Prentice-Hall. Englewood Cliffs, N.J.

Kumar, A. and Jadhav, S. 2007. Studies on propagation of phalsa (Grewia asiatica L.) by cutting. M.Sc. Thesis University of Agriculture Sciences, Dharwad (Karnataka).

Langhans, R. W. (1955). Mist for growing plants. Farm Res. (Cornell Univ.) 21(3): 3.

Luqman, M., Ali, N. and Sajid, M. 2004. Effect of different concentrations of indoles-butyric acid (IBA) on semi hard wood guava cuttings. Sarhad J. Agri., 20(2): 219-222.

Mitra, G.C. and Bose, N. 1954. Rooting and histological responses of detached leaves to BIndolebutyric acid with special reference to Boerhavia diffusa Linn. Phytomorphology, 7: 370.

Nanda, K.K. and Anand, V.K. 1970. Seasonal changes in auxin effects on rooting of stem cuttings of Populus nigra and its relationship with mobilization of starch. Physio. Pl., 23: 99-107.

Oni, O. 1987. Effect of Auxins on the Rooting of Stem Cuttings of Terminalia superba (Engl. and Diels). In: Oguntala, A.B., Ed., The Role of Forestry in a Depressed Economy, Proceedings of the 17th Annual Conference of the Forestry Association of Nigeria, Ikeja, 6-10 December 1987, 43-48.

Salunkhe, D. K. and Desai, B. B. 1984. Postharvest Biotechnology of Vegetables. Vol. 2. pp.70-75 CRC Press, Inc. Boca Raton, Florida, USA. 193p.

Singh K.K. and Tomar Y.K. 2015. Effect of planting time and indole butyric acid levels on rooting of woody cuttings of phalsa (Grewia asiatica L.). HortFlora Res. Spectrum, 4(1): 39-43.

Singh, K.K., Chauhan, J.S., Rawat, J.M.S. and Rana, D.K. 2015. Effect of different growing conditions and various concentrations of iba on the rooting and shooting of hardwood cutting of phalsa (Grewia asetica 1.) Under valley condition of Garhwal Himalayas. Plant Archives. 15(1):131-136.

Singh, K.K., Rawat, J. M. S. and Tomar, Y. K. 2011. Influence of Iba on Rooting Potential of Torch Glory Bougainvillea glabra During Winter Season. J. Hort. Sci. \& Orn. Plants., 3(2): 162-165.

Singh. S. and Singh, K.K. 2016. Effect of various concentrations of IBA and types of stem cuttings on the performance of rooting in Sweet Orange (Citrus sinensis 1. Osbeck) cv. Malta under mist. The Bioscan. 11(2): 903-906.

\section{How to cite this article:}

Krishan Kumar Singh. 2017. Multiplication of Phalsa (Grewia asetica L.) Cv. Dwarf Type through Hardwood Stem Cutting Under Srinagar Garhwal Himalayas. Int.J.Curr.Microbiol.App.Sci. 6(2): 1173-1178.

doi: http://dx.doi.org/10.20546/ijcmas.2017.602.132 